\title{
THE FORMATION OF DIRT GONES ON MOUNT RUAPEHU, NEW ZEALAND
}

\author{
By L. O. KRENEK \\ (Wanganui, New Zealand)
}

\begin{abstract}
Due to the abnormally warm summers of 1955 and 1956 the glaciers of Mount Ruapehu deteriorated to such an extent that the ash layer of the eruption of 1945 was exposed everywhere. This caused a development of ice cones similar to those occurring in Iceland. Various factors, especially heavy crevassing, which took place at the same time, are responsible for the different ways of development of dirt cones on Ruapehu.

Zusammenfassung. Die ungewöhnlich warmen Sommer I 955 und i 956 verursachten ein ausserordentlich starkes Abschmelzen der Gletscher des Mount Ruapehu, wodurch überall die Aschenlage des Ausbruchs von 1945 freigelegt wurde. Dies brachte eine Entwicklung von Eiskegeln mit sich, ähnlich wie sie in Island beobachtet wurden. Aus verschiedenen Gründen, besonders aber durch Auftreten von starker Zerklüftung, entwickelten sich die Eiskegel hier in verschiedener Weise.
\end{abstract}

THE abnormally warm summer of 1955 -temperatures were on the average $3.2^{\circ} \mathrm{F}$. above normal from November 1954 to May I955-caused a very considerable shrinkage of all the glaciers of Ruapehu, especially of the Whakapapa Glacier, which covers the northern slopes of the mountain. This glacier receded $94 \mathrm{~m}$. in one year, a very considerable amount for such a small glacier (length $\mathrm{I} \cdot 8 \mathrm{~km}$.), but the shrinkage in area and volume was far more impressive. No exact measurements of the amount of downwasting are available, but there are many indications that it must have been of the order of 10 to $15 \mathrm{~m}$. on the upper Whakapapa. Professor R. Finsterwalder states ${ }^{\mathrm{I}}$ that during the years 1920 to $195^{\circ}$ the surface of the Alpine glaciers was lowered on the average by $0.61 \mathrm{~m}$. per annum. Assuming a decrease of only Io $\mathrm{m}$. on Ruapehu in 1955 this would therefore be equivalent to 6 years of downwasting in the Alps.

At the same time heavy crevassing developed so that the surface of the glacier, which is normally quite smooth (see Dr. N. E. Odell's Fig. 4 in this Fournal ${ }^{4}$ ) was completely broken up at the end of the summer.

Owing to the large amount of ablation the ash layer of the eruption of I 945 was already exposed in mid-January, and gave the névés a nearly black appearance. On the upper Whakapapa the ash was from 25 to $30 \mathrm{~cm}$. thick. As reports of the r 945 eruption state that "ash lay up to 3 inches thick on the upper slopes" ${ }^{2}$ that original layer must have been considerably augmented by wind-blown ash from the surrounding mountains and by the many streams of melt water heavily charged with ash.

Because the ash protected the ice underneath, the dividing line between ash-free and ash-covered ice appeared from below like a solid wall of ice several feet high, covered by a black ribbon. This wall receded fairly rapidly up the glacier, about one to two metres a day.

Further down, the surface of the glacier was dotted with hundreds of dirt cones. They were quite regularly arranged, mainly in parallel lines along the crevasses, more rarely at right angles to them (Fig. I, p. 310). Nearly all were found in the upper half of the Whakapapa above $2250 \mathrm{~m}$., but not beyond $2500 \mathrm{~m}$., where the glacier was still covered by ash. Their average height was about $2 \mathrm{~m}$., but they ranged from $5^{0} \mathrm{~cm}$. to $5 \mathrm{~m}$. All consisted of an ice core covered by a layer of black ash 5 to $7 \mathrm{~cm}$. thick. Most of the dirt cones therefore presented a similar picture to those occurring on Skaftárjökull, described by Swithinbank, ${ }^{3}$ but were somewhat steeper, the angle of the sides being 45 to 55 degrees. They did not show a V-shaped groove at the apex of the ice cone.

Two modes of the formation of dirt cones were observed. The development of those along the crevasses probably occurred in the way suggested by Swithinbank. ${ }^{3}$ As shown in Fig. 2, little streams of melt water, heavily charged with ash, deposited their loads in the nearest crack. These deposits protected the ice underneath, so that with the constant lowering of the surface, lines of dirt cones developed inside most of the crevasses. (Figs. I and 3.)

On Ruapehu, the "cracks" were normally shallow depressions, 30 to $60 \mathrm{~cm}$. wide, and, in 
the beginning, seldom more than $30 \mathrm{~cm}$. deep. Many of these developed later into crevasses. Swithinbank's diagrams could be modified in the way shown in Fig. 5 to explain developments on Ruapehu. First, ash was collected in shallow depressions $(a)$. When the surface was lowered by ablation, the ash reached the surface and was spread $(b)$. As ablation proceeded, the ash-layer protected the ice underneath so that it rested on an ice pillar $(c)$. Ash fell down and collected at the base, so that the top of the pillar melted and the base was protected. The pillar changed slowly to a cone $(d$ and $e$ ).

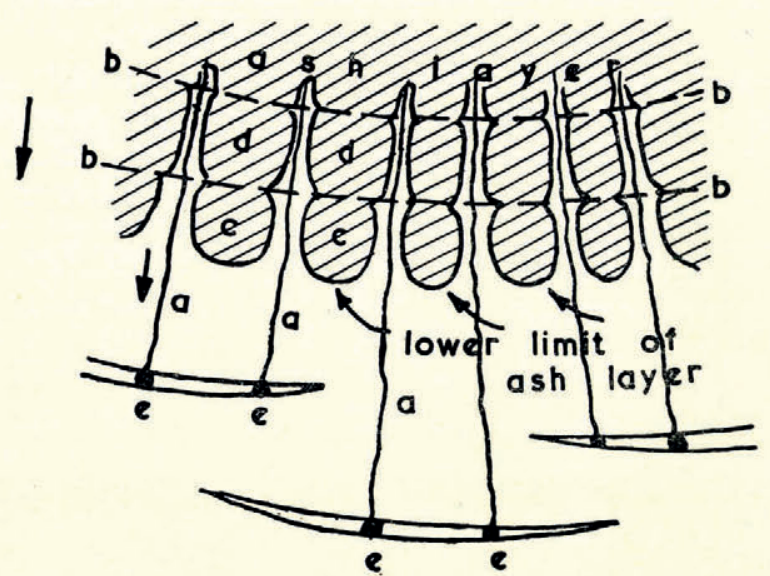

Fig. 2. Ash layer on Whakapapa Glacier dissected by streams of melt water $(a)$ and opening crevasses $(b)$. Cut-off parts of ash layer may develop into dirt cones $(c$ and $d)$. Streams deposit ash in crevasses $(e)$

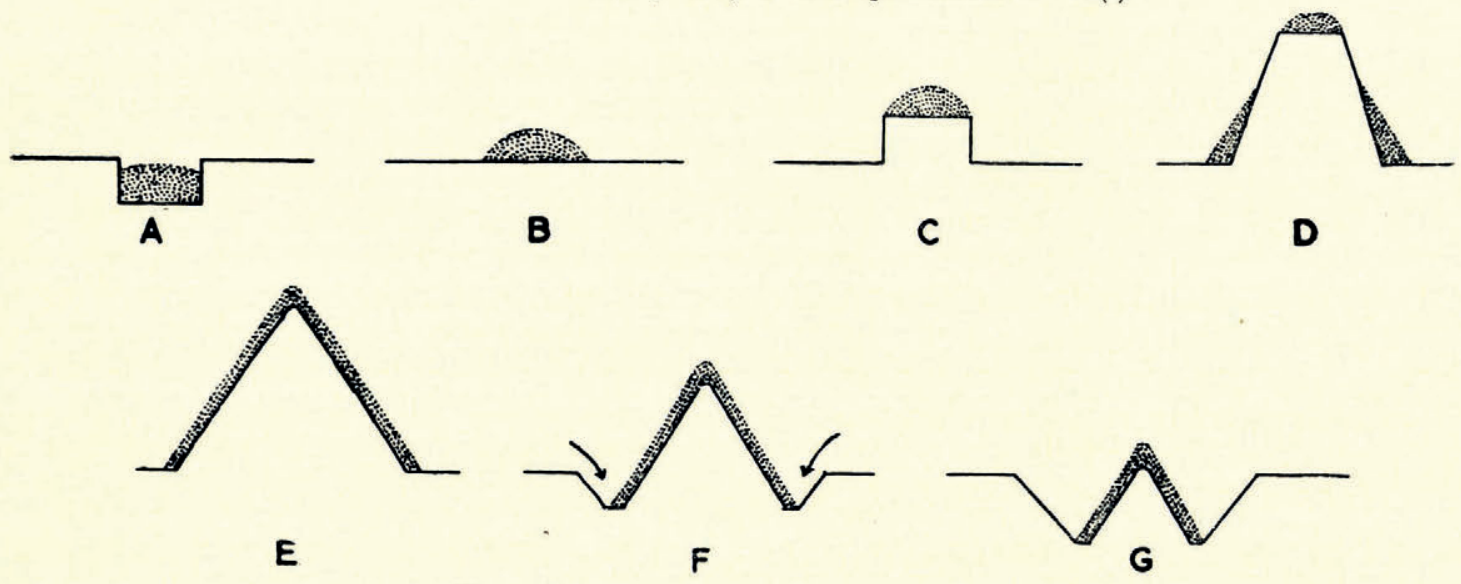

Fig. 5. Development of dirt cones on Mt. Ruapehu

Dirt cones at right angles to the crevasses originated in a different way. The layer of ash was cut into many parallel ridges by the streams of melt water rushing down from the head of the glacier. At the same time crevasses began to open up, so that some parts of the ridges subsided, leaving a hummocky surface (Fig. 4). The hummocks developed into dirt cones where the ash-layer between them disappeared. These dirt cones were therefore formed on the spot, between the crevasses. At the side of the glacier, where crevassing did not take place, or where it developed later, these ridges, parallel to the flow of the glacier, were preserved. They gained rapidly in height as soon as the channels between them were swept clean of ash, and erosion and ablation combined to deepen the channels. 
Four weeks later, in March, about half of the dirt cones had disappeared; and the remainder were on the whole less conspicuous. In April, most of the lines of dirt cones had disappeared completely. Only a few isolated ones, mostly of the second type, that is those developed in situ, were still visible. They had grown to considerable size in the meantime. What caused the gradual disappearance of all these hundreds of dirt cones?

Two causes are suggested. First, the heavy, warm rains in February must in many cases have washed down the protecting cover. Some cones grew to such a height that the layer of ash was thinned out so much that it no longer protected the underlying ice.

A careful comparison of all the photographs taken during that period suggests an additional reason. The photographs show that in many cases wide, open crevasses occupied the place of the lines of dirt cones. It therefore seems most likely that the gradually opening crevasses slowly swallowed up the cones. Some were tilted in the process, lost their cover and disappeared rapidly. Some retained their black cover and therefore kept their shape while slowly sinking. Fig. 6 shows quite clearly a few dirt cones just sticking out of the crevasses. The last two diagrams in Fig. 5 show the last stages of the cycle, the gradual disappearance of a cone. When crevasses open wider than the base of the cone, the cone subsides $(f)$. Much dust is now removed at the base of the cone by melt water (arrows). The dirt cone now disappears rapidly, partly by subsidence, partly by the removal of dust $(g)$.

In the normal course of events, dirt cones will increase in height as long as ablation is more vigorous than the opening of crevasses; they decrease when the widening of crevasses is more pronounced than ablation.

In the latter part of the summer erosion played an increasingly important part in the shaping of the glacier surface. This was especially noticeable in the area between the summit plateau (an ice mass which covers the North crater of Ruapehu 5 ) and the Whakapapa. There the melt waters cut deep gorges into the ice, leaving fantastic ice ridges and pyramids standing between them. As the surface of the plateau was lowered, the rim of the North Crater emerged nearly everywhere. Finally connexions between the two ice masses were severed completely and huge ice pyramids were left stranded on the lowest saddles of the rim of the crater. The ice pyramid depicted in Fig. 7 shows the result of three stages of development. First a dirt cone was formed in the way described previously (dirt cones developed in situ). Then, deep channels cut by the melt waters of the summit plateau separated it completely from the neighbouring area; its relative height increased rapidly. Finally, when erosion reached the bedrock, the cone was tilted backwards towards the interior of the North Crater. The thin black lines represent annual dirt strata, the thick lines indicate ash layers from eruptions of Ruapehu or Ngauruhoe.

Dirt cones appeared again in the summer of $195^{6}$ on some of the glaciers, although much later in the year. There was less crevassing. The last stage, the disappearance of dirt cones in crevasses, was not observed in the area visited in $195^{6 .}$

$M S$. received 4 December 1957

\section{REFERENGES}

1. Finsterwalder, R. Photogrammetry and glacier research. Fournal of Glaciology, Vol. 2, No. I 5, 1954 , p. $306-15$. 2. Beck, A. C. Volcanic Activity at Mt. Ruapehu from August to December, 1945. New Zealand Fournal of Science and Technology, Sect. B, Vol. 31, i949, p. I-13.

3. Swithinbank, C. The origin of dirt cones on glaciers. Fournal of Glaciology, Vol. 1, No. 8, 1950, p. 46 I-65.

4. Odell, N. E. Mount Ruapehu, New Zealand: observations on its crater lake and glaciers. Fournal of Glaciology,

Vol. 2, No. 18, I 955 , p. $599-605$.
5. Friedlaender, B. Some notes on the volcanoes of the Taupo district. Transactions of the New Zealand Institute, Vol. 31, 1898, p. 498-510.

\section{OTHER AUTHORITIES}

Klebelsberg, R. von. Handbuch der Gletscherkunde and Glazialgeologie. Bd. I. Wien, Springer Verlag, r948, p. 105,

109.
Lliboutry, L. Banding and volcanic ash on Patagonian glaciers. Fournal of Glaciology, Vol. 3, No. 21, 1957, p. 20-25. 


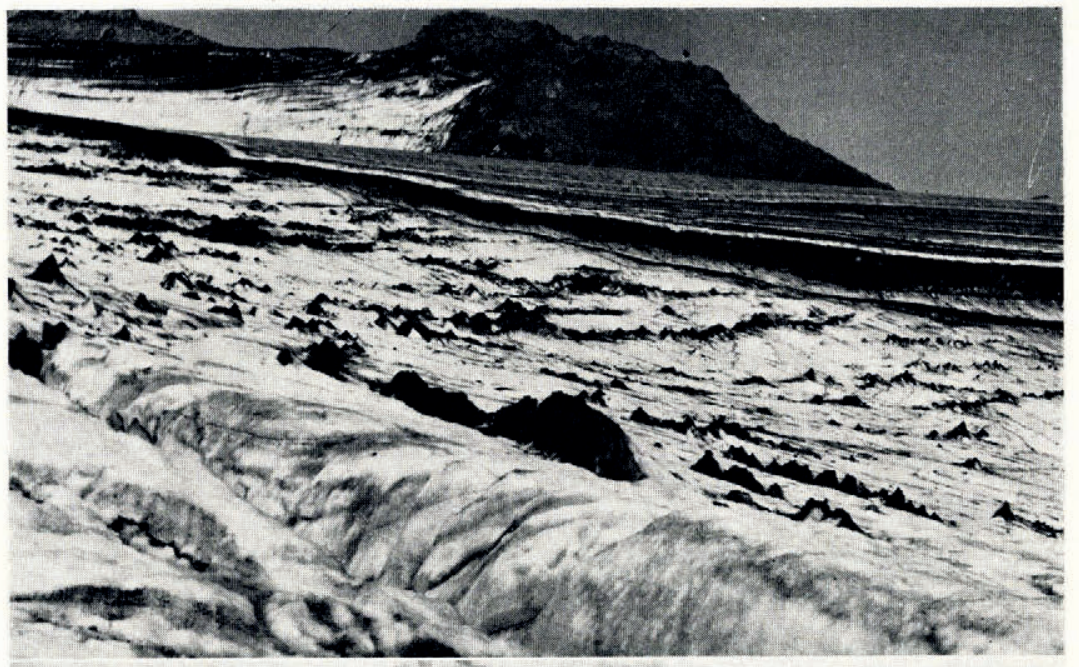

Fig. I (top). Lines of dirt cones on the upper Whakapapa Glacier. In the background melt borders of volcanic ash Fig. 3 (centre left). Dirt cones along a crevasse. The ash cover is $5-7 \mathrm{~cm}$. thick. Pinnacle ridge in background

Fig. 4 (centre right). Hummocky surface on the upper Whakapapa Glacier. The hummocks developed later into isolated dirt cones

Fig. 6 (bottom left). Lines of submerged dirt cones, Whakapapa Glacier. In the foreground centre and right the top of some dirt cones are still visible. Melt borders of volcanic ash are visible in the background

Fig. 7 (bottom right). Large ice cone on the saddle of the North Crater, Ruapehu. The cone has been tilted towards the interior of the crater. The thin black lines indicate annual dirt strata. The thick lines represent ash layers of volcanic eruptions from Ruapehu or Ngauruhoe
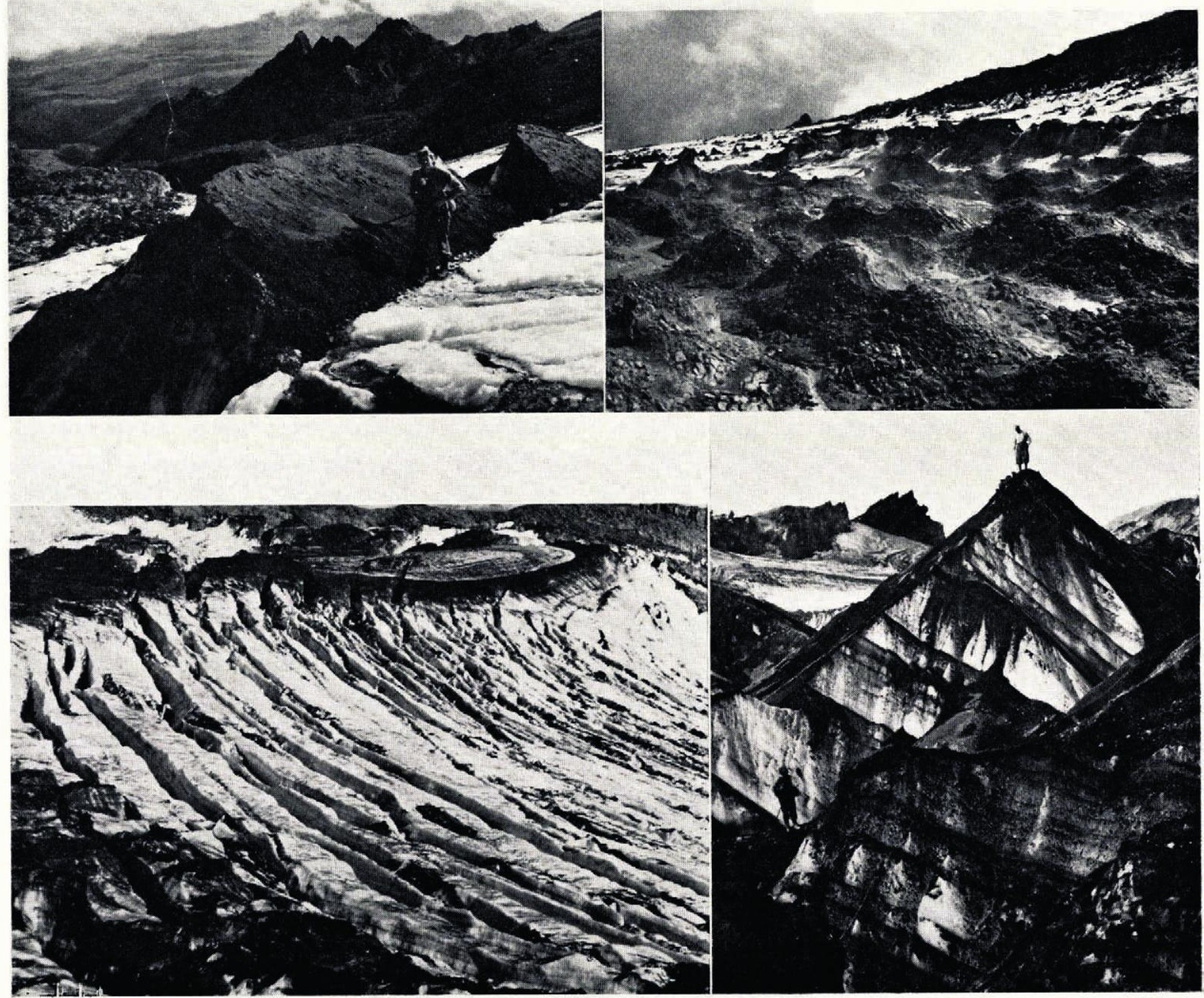